\title{
The impact on production and costs after the acquisition of an airline by a competitor in Brazil: a Cobb-Douglas function application
}

\author{
José Alexandre Tavares Guerreiro Fregnani ${ }^{1}$, Tarik Hadura Orra ${ }^{2}$, \\ Rogéria de Arantes Gomes Eller ${ }^{3}$, Bento Silva de Mattos ${ }^{4}$ \\ ${ }^{1}$ Technological Institute of Aeronautics - ITA, eng.fregnani@hotmail.com \\ ${ }^{2}$ Technological Institute of Aeronautics - ITA, tarikorra@gmail.com \\ ${ }^{3}$ Technological Institute of Aeronautics - ITA, rogeria@ita.br \\ 4Technological Institute of Aeronautics - ITA, bmattos@ita.br
}

\section{Recebido:}

13 de novembro de 2017

Aceito para publicação:

15 de abril de 2018

Publicado:

30 de abril de 2019

Editor de área:

Li Weigang

\section{Keywords:}

Air transport management,

Productivity,

Airline operational costs,

Cobb-Douglas function,

Air transport in Brazil.

\section{Palavras-chaves:}

Gestão de transporte aéreo,

Produtividade,

Custos operacionais de empresas

aéreas,

Função Cobb-Douglas,

Transporte aéreo no Brasil.

DOI:10.14295/transportes.v27i1.1512

OPEN

Access

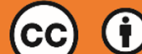

\begin{abstract}
Objective of this paper is to analyze the impact on production and air transport costs as result of the acquisition of an airline in growth by its dominant competitor with similar operational pattern. Two Cobb-Douglas functions, related to production and costs respectively, were used for such analysis, considering the periods before and after the acquisition. We take as example for analysis the acquisition of Webjet Linhas Aéreas SA by VRG Linhas Aéreas (GOL Linhas Aéreas Inteligentes) officially consolidated in October 2012. The results demonstrate that the acquisition of the market growing company with similar operational pattern provided negative impact on the company's productivity, showing loss of operational efficiency and increased costs, not absorbing in full production potential that the acquisition of the company could bring. Such methodology demonstrated to be effective in the impact analysis of such kind of operations since permits conclusions based on econometric results to be used by decision makers.
\end{abstract}

\section{RESUMO}

O objetivo deste artigo é analisar o impacto sobre os custos de produção e transporte aéreo como resultado da aquisição de uma empresa aérea em crescimento por sua competidora dominante de operação similar. Duas funções Cobb-Douglas, relacionados à produção e custos respectivamente, foram utilizados para tal análise, considerando os períodos anteriores e posteriores à aquisição. Toma-se como exemplo para análise a aquisição da Webjet Linhas Aéreas SA pela GOL Linhas Aéreas Inteligentes, consolidada oficialmente em outubro de 2012. Os resultados demonstram que a aquisição da empresa em crescimento proporcionou impacto negativo na produtividade da empresa dominante, apresentando perda de eficiência operacional, aumento de custos e não absorvendo pleno potencial de produção que a aquisição da primeira pudesse trazer. Tal metodologia demonstrou ser eficaz na análise de impacto desse tipo de operação, uma vez que permite que conclusões baseadas em resultados econométricos sejam utilizadas pelos tomadores de decisão.

\section{INTRODUCTION}

Production in the air transport industry is measured by the amount of revenue generated during a certain period of operations divided by the total number of passengers transported times the total distance traveled (RPK, revenue passenger-kilometer). The correct determination of this metric is paramount for airlines, since it is used as key performance indicator applied during the capacity planning process, also involving fleet and network management. Therefore, the 
adequate selection of inputs is a key factor for success. Fuel consumption, fleet size and available seat kilometers are usually the major inputs considered in this process (Bettini and Oliveira, 2011).

Nowadays, sophisticated data analysis applications have been developed to accurately estimate the best model for the air transport production function for airlines with a selected set of inputs. However, since the early days of airlines (when computational power was a limiting factor for quick decisions) simple analytical models have also been explored and have demonstrated relatively good accuracy in this kind of process. A common approach, frequently adopted by airlines worldwide, is to model the RPK through a Cobb-Douglas function, due to its mathematical simplicity and facility to derive accurate results with relatively few inputs under consideration.

\section{The Cobb-Douglas Function}

In fact, the Cobb-Douglas function has been widely used in microeconomics since the early days to represent the relationship between a selected output and various inputs, revealing itself to be a suitable mathematical approach to model production functions. It was first proposed by Knut Wicksell (an English mathematician and statistician) and was verified to meet the statistical evidence of the shipbuilding industry by Paul Douglas and Charles Cobb. After the construction of the Titanic and Lusitania liners, a textbook on mathematical development of production in general was published in 1928 (Cobb, 1928). One way to estimate the analytical production function is to elaborate it in accordance with an exponential model that allows the analysis of the marginal productivity theory in a simple and efficient way. The general formulation of the Cobb-Douglas function is then shown in Equation 1

$$
Y=A \cdot \prod_{i}^{n} X_{i}^{\alpha i}
$$

where $Y$ is the output, $x_{i}(i=1 \ldots n)$ the considered inputs, $\alpha_{i}$ are the $Y$ elasticities in relation to input $X_{i}$ and $A$ is a proportionality constant. Using this mathematical model is advantageous as the elasticities $\alpha_{i}$ may be easily determined via linear multivariate regression, given a set of observed inputs $X_{i}$ and outputs $Y_{i}$, without any complex derivate calculations.

The logarithm of the Cobb-Douglas function may also be adopted without affecting the conclusions in an adverse manner, where the $\alpha_{i}$ coefficients (or elasticities) can be readily determined by linear regression as well as by ordinary least squares from a set of selected historical data inputs.

The logarithmic form is therefore expressed by:

$$
\ln (Y)=\ln (A)+\sum_{i=1}^{n} \alpha i \ln \left(X_{i}\right)
$$

It is also important to notice that when adding production functions of two companies using similar technologies, it may be mathematically proved that the equation is $Y 1+Y 2=A \cdot \prod_{i}^{n}(X 1 i+X 2 i)^{a i}$ true if the ratio of the inputs of the two companies $\mathrm{X} 1_{\mathrm{i}} / \mathrm{X} 2_{\mathrm{i}}$ is constant for all $\mathrm{i}=1 . . \mathrm{n}$ and $\sum_{1}^{n} \alpha i=1$. This means that the function may not work in aggregated cases or on macro levels (Hong Bao, 2008).

Finally, it is also possible to transcend the use of the Cobb-Douglas function for the production costs. The traditional way to solve the problem of modeling the cost is considering the input price vector $\left(\mathrm{w}_{\mathrm{i}}\right)$ variables, and even the amount of inputs used $(Y)$ as dependent variables. The equation cost of Cobb-Douglas for costs is then represented by the following function:

$$
\ln (C)=\alpha 0+\alpha y \cdot \ln (Y)+\sum_{1}^{n} \alpha i \cdot \ln (w i)
$$


An important property of the aforementioned function is that if all inputs are multiplied by the factor $\mu$, the $Y$ function will be multiplied by $\mu \mathrm{r}$ where $\mathrm{r}=\sum_{i}^{n} \alpha i$ represents the returns to scale (or factor of homogeneity). When $r=1$, returns to scale are constant, i.e., the $Y$ function is multiplied in proportion to the input. When $r<1$, there are diminishing returns to scale and when $r>1$, they are called increasing returns. According to Doganis (2001), returns to scale in air transport are generally decreasing due to the complexity of managing the availability of inputs. It is vital to observe that the production returns always refer to constant input prices, the quantities of inputs being the only variables.

\section{State-of-the-art}

In the last decades, several authors have been exploring the use of the Cobb-Douglas function in Air Transport. Caves et al. (1984) propose an analytical formula for determining the density of returns using the Cobb-Douglas function which is defined as the percentage increase of output due to the addition of $1 \%$ of all inputs, keeping both the route network as well as the demand and prices constant. This study defines the density factor (RD) as the inverse of the elasticity of the total cost for the production. If $\mathrm{RD}>1$ there will be increasing density returns (or economies of density); if $\mathrm{RD}=1$ there will be constant density returns and if $\mathrm{RD}<1$ there will be diminishing returns density (or diseconomies of density). Based on this research, Barros Jr (2011) produced a study showing that a "well-behaved" cost function must impose homogeneity on the level of prices of inputs and therefore $\sum_{1}^{n} \alpha i=1$.

Silveira (2003) studied in detail the Cobb-Douglas into an air transport application. For the first time, in this important research the main cost factors impacting the operations of a Brazilian airline were identified in domestic and international flights.

Fregnani et al. (2009) used the Cobb-Douglas function to estimate fuel-related costs in regional Brazilian airlines in regions that differ with respect to the proximity of the fuel distribution centers, with different sensitivity changes in the prices of this input. It was found that the logistics issue in the acquisition of this input is critical in the analyzed companies cost structure.

Martins et al. (2012) studied the effectiveness of the Cobb-Douglas function as a tool to determine productivity prediction of road transportation in Brazil, pointing out some similarities with air transport.

For the first time, Kuroda et al. (2012) proposed the evaluation of the impact on air transport of production as a result of the acquisition of VARIG GOL in 2003 (Kuroda et al., 2012), using historical data series from the first quarter of 2003 to the last quarter of 2007. The regression results showed that in the short term, there was a fall in productivity following the acquisition by the observed reduction in the share of labor in the results measured in terms of passenger kilometers. The inputs used in the analysis were: daily utilization rate of the aircraft, the average number of aircraft and number of employees.

More recently Yang and Zhu (2015) proposed to build a Cobb-Douglas function to measure the technical efficiency of airlines, considering an RPK analysis using labor expenses, fuel consumption and aircraft capital expenditure as inputs.

\section{objective}

The objective of this paper is to present a method to evaluate the impact on air transport production (expressed in terms of RPK - revenue per passenger kilometer) and average costs (expressed in terms of CASK - cost per available seat kilometer) after the acquisition of a Brazilian growing low-cost airline by its dominant competitor, using Cobb-Douglas functions. 


\section{METHODOLOGY}

In this study it is proposed to conduct the RPK and CASK impact study after the acquisition of Webjet Linhas Aéreas SA by VRG Linhas Aéreas (so called GOL airlines), officially consolidated in October 2012. On that date the Webjet 737-300 fleet (20 aircraft) was incorporated into GOL, together with company routes (18 common destinations) and employees. For that the following RPK and CASK models, derived from the Cobb-Douglas functions, are used:

$$
\begin{gathered}
R P K=\beta_{0} \cdot A S K^{\beta 1} \cdot C O M B^{\beta 2} \cdot F U N C^{\beta 3} \cdot A N V^{\beta 4} \\
C A S K=\alpha_{0} \cdot R P K^{\alpha 1} \cdot C_{-} C O M B^{\alpha 2} \cdot C_{-} F U N C^{\alpha 3} \cdot C_{-} M N T^{\alpha 4}
\end{gathered}
$$

On log-linear format:

$$
\begin{gathered}
\operatorname{Ln}(R P K)=\beta_{0}+\beta_{1} \cdot \operatorname{Ln}(A S K)+\beta_{2} \cdot \operatorname{Ln}(C O M B)+\beta_{3} \cdot \operatorname{Ln}(F U N C)+\beta_{4} \cdot \operatorname{Ln}(A N V) \\
\operatorname{Ln}(C A S K)=\alpha_{0}+\alpha_{1} \cdot \operatorname{Ln}(R P K)+\alpha_{2} \cdot \operatorname{Ln}\left(C_{-} C O M B\right)+\alpha_{3} \cdot \operatorname{Ln}\left(C_{-} F U N C\right)+\alpha_{4} \cdot \operatorname{Ln}\left(C_{-} M N T\right)
\end{gathered}
$$

where ASK: Total available seat kilometers offered;

COMB: Total Fuel Consumed (Million Liters);

FUNC: Total Number of Effective Staff;

ANV: Total number of company fleet aircraft;

$\beta \mathrm{i}: \quad$ Elasticity of production in relation to the considered inputs.

RPK: $\quad$ Revenue Passenger-kilometers (demand);

C_COMP: Consumed Fuel Cost per available seat kilometer (cents \$ / pax.km);

C_FUNC: Personnel Cost per available seat kilometer (cents \$ pax.km);

\begin{tabular}{|c|c|c|c|c|c|c|c|c|c|c|}
\hline $\begin{array}{c}\text { Data } \\
\text { Set }\end{array}$ & PERIOD & $\begin{array}{c}\text { RPK } \\
(\times 10 E 6)\end{array}$ & $\begin{array}{c}\text { ASK } \\
(\times 10 E 6)\end{array}$ & $\begin{array}{l}\text { Fuel Burned } \\
\left(10^{6} \text { liters }\right)\end{array}$ & $\begin{array}{l}\text { Number of } \\
\text { employees }\end{array}$ & $\begin{array}{c}\text { Average } \\
\text { distance } \\
\text { flown }(\mathrm{km})\end{array}$ & $\begin{array}{l}\text { Number } \\
\text { of Aircraft }\end{array}$ & $\begin{array}{c}\text { CASK } \\
\text { (cents R\$ } \\
\text { per PAX.km) }\end{array}$ & $\begin{array}{c}\text { RASK } \\
\text { (cents R\$ } \\
\text { per PAX.km) }\end{array}$ & $\begin{array}{c}\text { YIELD } \\
\text { (cents R\$ } \\
\text { per pax.km) }\end{array}$ \\
\hline \multirow{12}{*}{ 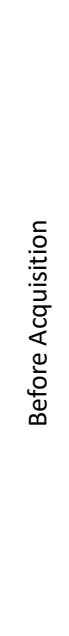 } & $1 \mathrm{T09}$ & 5,8 & 9,5 & 306 & 16799 & 877 & 107 & 14,8 & 15,9 & 23,8 \\
\hline & 2Т09 & 5,8 & 9,6 & 308 & 17195 & 874 & 108 & 13,5 & 14,5 & 21,5 \\
\hline & зт09 & 7,2 & 10,2 & 330 & 17678 & 896 & 109 & 13,7 & 14,7 & 18,9 \\
\hline & 4Т09 & 7,8 & 10,6 & 346 & 17963 & 894 & 109 & 14,2 & 15,3 & 18,1 \\
\hline & $1 \mathrm{~T} 10$ & 8,0 & 11,2 & 360 & 18325 & 895 & 108 & 13,8 & 15,5 & 19,5 \\
\hline & $2 \mathrm{~T} 10$ & 6,7 & 11,1 & 351 & 18686 & 902 & 110 & 13,9 & 14,4 & 20,9 \\
\hline & 3Т10 & 8,3 & 11,6 & 377 & 18649 & 920 & 112 & 13,8 & 15,4 & 19,4 \\
\hline & 4T10 & 8,3 & 11,7 & 377 & 18776 & 910 & 113 & 13,7 & 16,0 & 20,4 \\
\hline & 1T11 & 8,6 & 11,9 & 382 & 18706 & 930 & 111 & 14,5 & 15,4 & 19,8 \\
\hline & $2 \mathrm{~T} 11$ & 7,6 & 11,4 & 358 & 18691 & 893 & 109 & 16,2 & 13,8 & 18,3 \\
\hline & 3Т11 & 8,9 & 12,5 & 390 & 18606 & 905 & 111 & 15,4 & 14,8 & 18,4 \\
\hline & $4 \mathrm{~T} 11$ & 9,3 & 14,2 & 462 & 20525 & 889 & 138 & 15,8 & 15,5 & 21,3 \\
\hline
\end{tabular}

C_MNT: Maintenance Cost per available seat kilometer (cents \$ / pax.km);

ai: $\quad$ Elasticity of costs in relation to the considered inputs.

Table 1: GOL Airlines air transport data 
Table 1: GOL Airlines air transport data (cont)

\begin{tabular}{|c|c|c|c|c|c|c|c|c|c|c|}
\hline $\begin{array}{c}\text { Data } \\
\text { Set }\end{array}$ & PERIOD & $\begin{array}{c}\text { RPK } \\
(x 10 E 6)\end{array}$ & $\begin{array}{c}\text { ASK } \\
(\times 10 E 6)\end{array}$ & $\begin{array}{l}\text { Fuel Burned } \\
\text { (10 liters) }\end{array}$ & $\begin{array}{l}\text { Number of } \\
\text { employees }\end{array}$ & $\begin{array}{c}\text { Average } \\
\text { distance } \\
\text { flown }(\mathrm{km})\end{array}$ & $\begin{array}{l}\text { Number } \\
\text { of Aircraft }\end{array}$ & $\begin{array}{c}\text { CASK } \\
\text { (cents R\$ } \\
\text { per PAX.km) }\end{array}$ & $\begin{array}{c}\text { RASK } \\
\text { (cents RS } \\
\text { per PAX.km) }\end{array}$ & $\begin{array}{c}\text { YIELD } \\
\text { (cents R\$ } \\
\text { per pax.km) }\end{array}$ \\
\hline \multirow{14}{*}{ 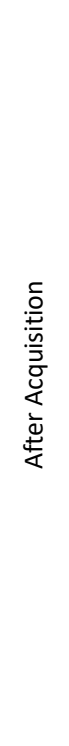 } & $1 \mathrm{~T} 12$ & 9,50 & 13,99 & 446 & 20548 & 888 & 138 & 15,43 & 15,48 & 20,25 \\
\hline & $2 \mathrm{~T} 12$ & 8,70 & 12,51 & 403 & 18966 & 866 & 129 & 17,48 & 14,64 & 18,43 \\
\hline & 3Т12 & 9,59 & 13,00 & 417 & 18356 & 868 & 131 & 16,85 & 15,30 & 18,37 \\
\hline & $4 \mathrm{~T} 12$ & 8,62 & 12,36 & 390 & 17676 & 885 & 127 & 18,46 & 17,16 & 21,76 \\
\hline & $1 \mathrm{~T} 13$ & 8,29 & 12,33 & 374 & 16470 & 905 & 122 & 16,07 & 16,89 & 22,99 \\
\hline & $2 \mathrm{~T} 13$ & 8,25 & 12,18 & 370 & 16645 & 891 & 119 & 16,01 & 15,72 & 20,88 \\
\hline & 3Т13 & 8,66 & 11,05 & 376 & 16209 & 894 & 120 & 17,62 & 17,92 & 23,58 \\
\hline & $4 \mathrm{~T} 13$ & 9,48 & 12,68 & 391 & 16319 & 899 & 124 & 20,24 & 21,52 & 25,85 \\
\hline & $1 \mathrm{~T} 14$ & 9,54 & 12,53 & 386 & 16157 & 909 & 126 & 18,74 & 19,90 & 23,95 \\
\hline & 2T14 & 8,73 & 11,62 & 363 & 16302 & 903 & 124 & 20,16 & 20,50 & 24,40 \\
\hline & 3Т14 & 9,46 & 12,20 & 380 & 16354 & 903 & 125 & 18,92 & 20,18 & 23,15 \\
\hline & $4 \mathrm{~T} 14$ & 10,35 & 13,16 & 409 & 16875 & 932 & 129 & 19,45 & 20,75 & 23,58 \\
\hline & $1 \mathrm{~T} 15$ & 10,17 & 13,03 & 402 & 16825 & 951 & 130 & 18,03 & 19,22 & 21,90 \\
\hline & $2 \mathrm{~T} 15$ & 9,11 & 11,87 & 371 & 16830 & 912 & 125 & 20,06 & 17,95 & 20,26 \\
\hline
\end{tabular}

\section{PRELIMINARY DATA ANALYSIS}

In this session we conduct a preliminary analysis of the RPK and CASK trends before and after the acquisition, as function of selected input variables, according to Figures $1 \mathrm{a}, 1 \mathrm{~b}, 2 \mathrm{a}, 2 \mathrm{~b}, 3 \mathrm{a}, 3 \mathrm{~b}, 4 \mathrm{a}$ and $4 \mathrm{~d}$. In this scope, the following observations are relevant:

Figure 1a shows that the RPK scattering increased with ASK after the acquisition, suggesting that both ASKs (from GOL and Webjet) were not complementary, implying that the superposition of networks from both companies may be presenting competing routes. This is also suggested in Figure 1b where a significant increase in average costs (CASK) is observed after the acquisition, never equalized to pre-acquisition levels.

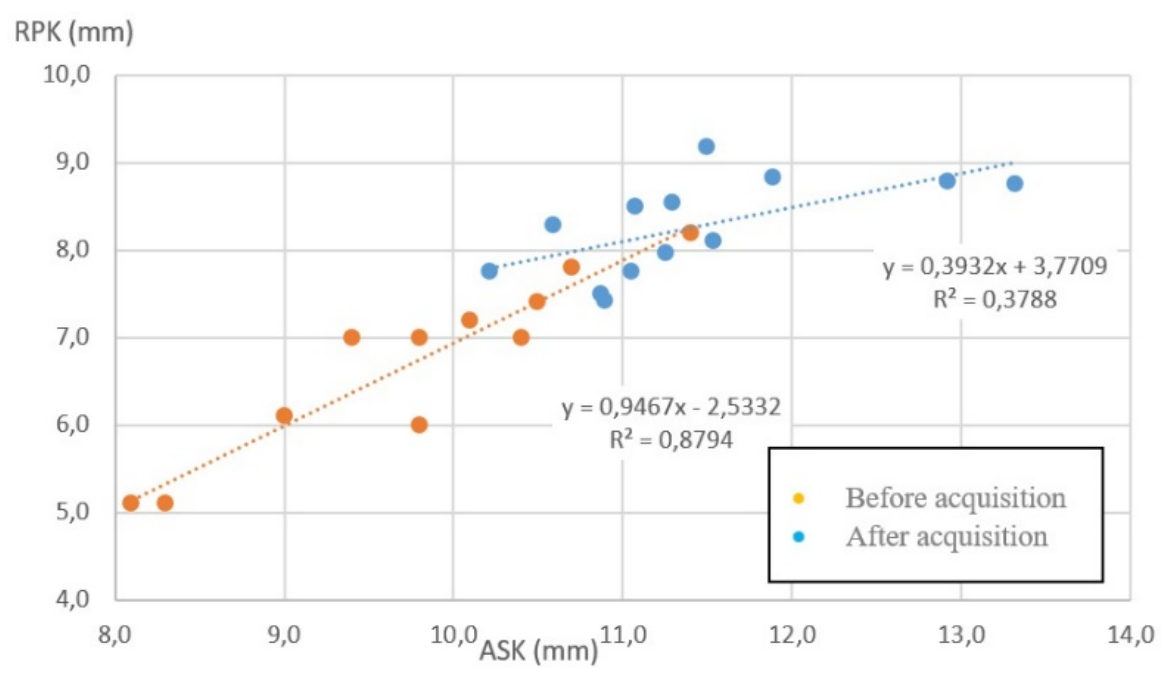

Figure 1a. RPK x ASK 
Figure 2a shows that, after the acquisition, the RPK continued insensitive to the increased number of employees, thus suggesting a drop in the company's efficiency to generate revenue. Figure $2 b$ shows a significant increase of CASK after the acquisition, almost returning to the initial levels prior to the acquisition, after Webjet's employees were incorporated.

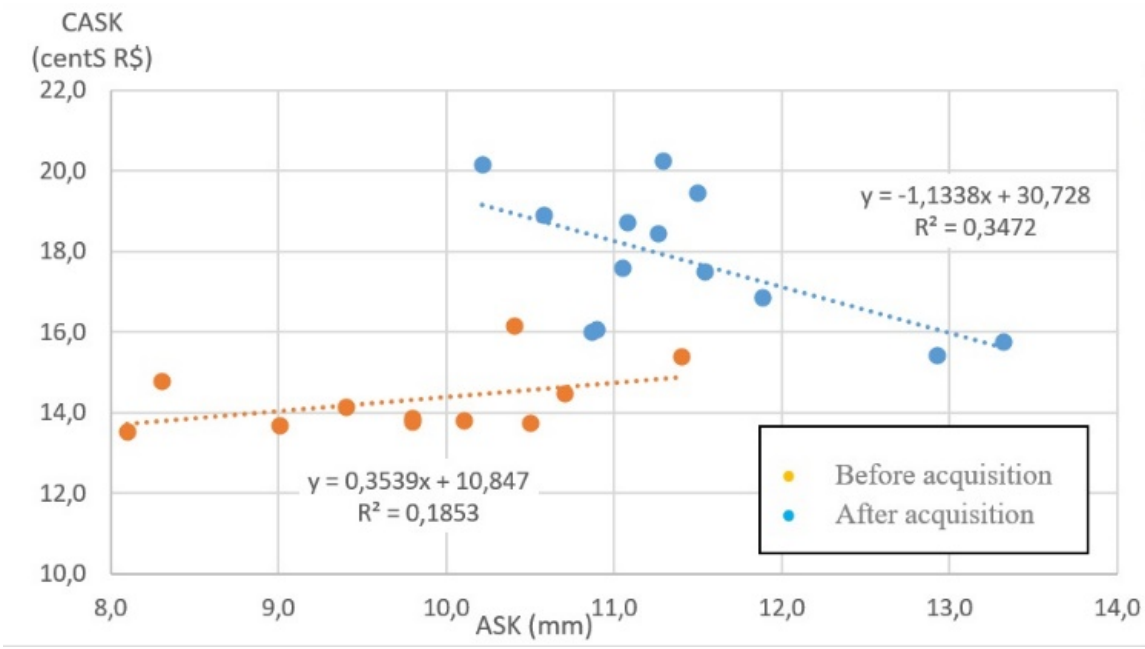

Figure 1b. CASK x ASK (Source: www.voegol.com.br)

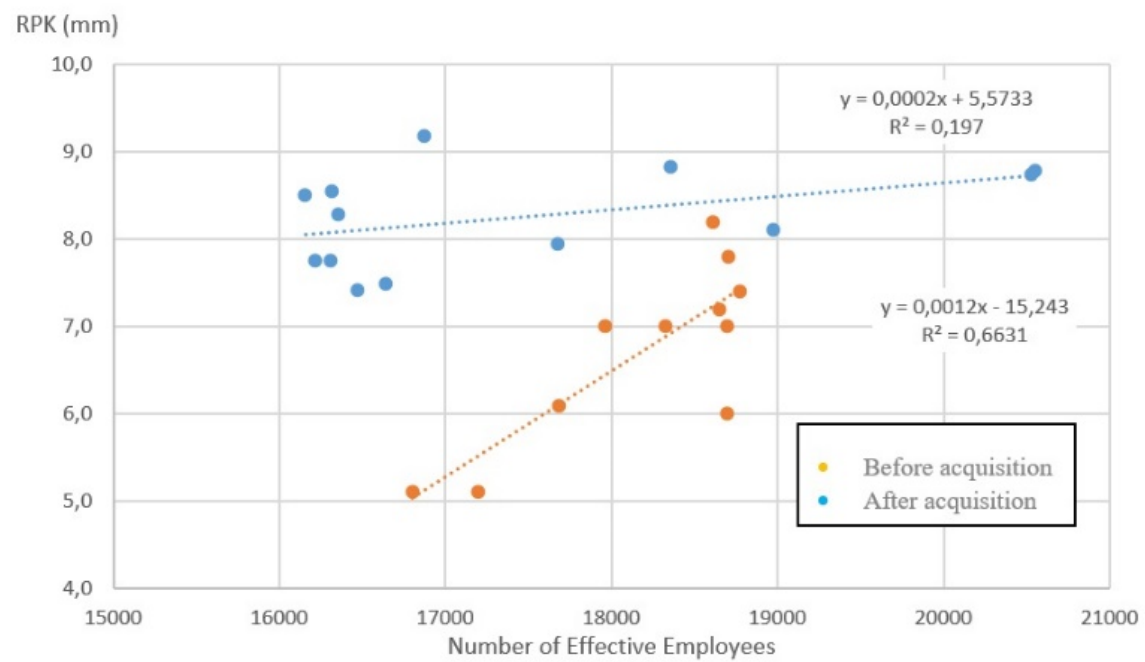

Figure 2a. RPK x Number of Employees (Source: www.voegol.com.br)

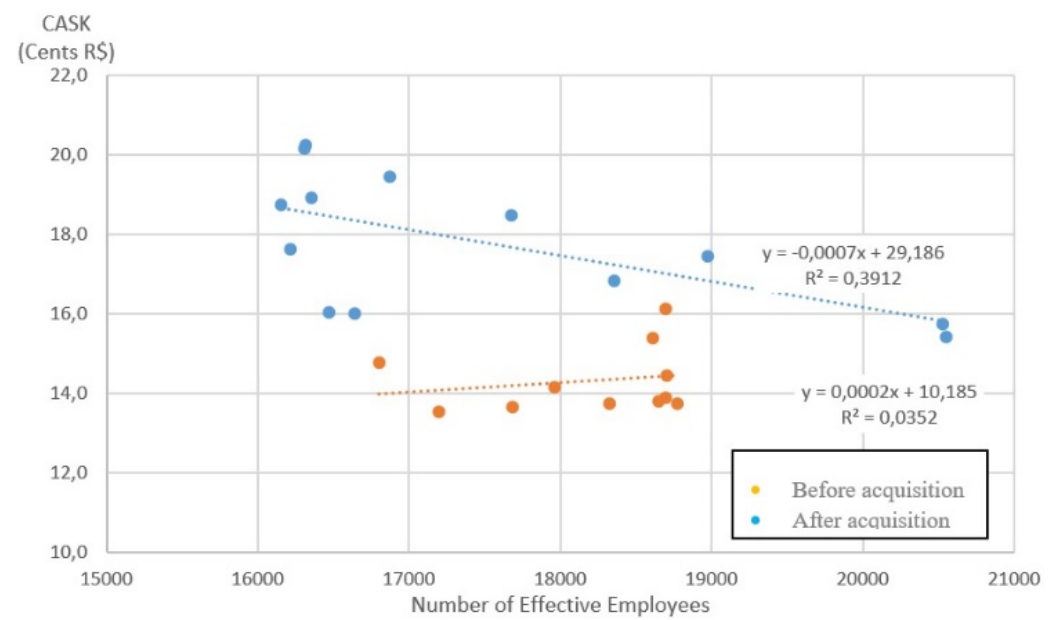

Figure 2b. CASK x Number of Employees (Source: www.voegol.com.br) 


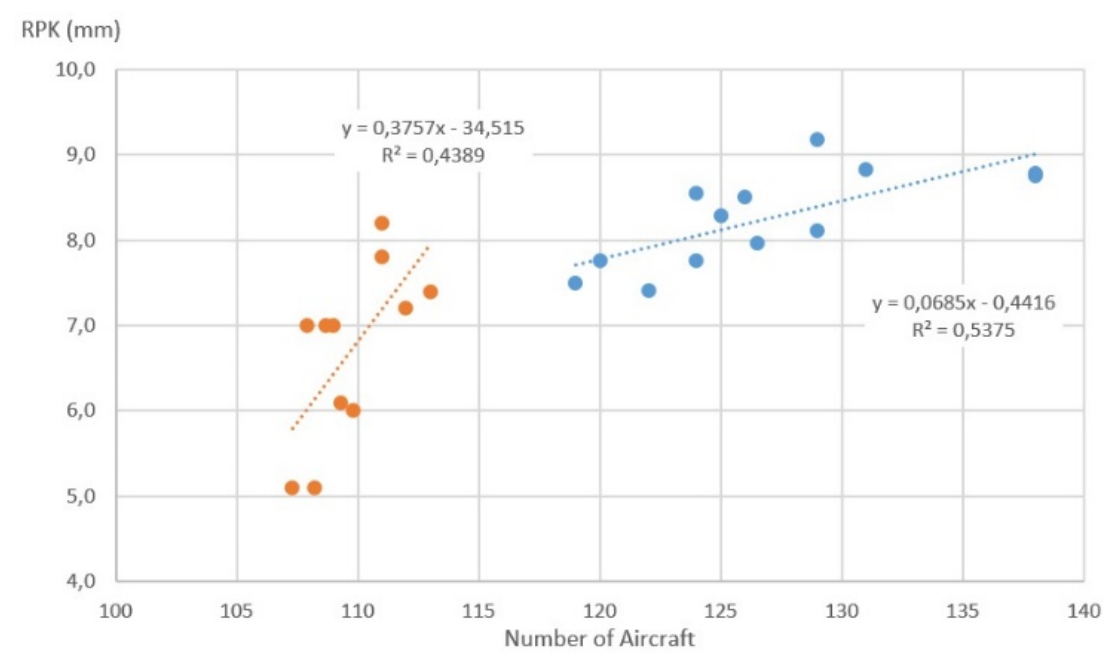

Figure 3a. RPK x Fleet size (Source: www.voegol.com.br)

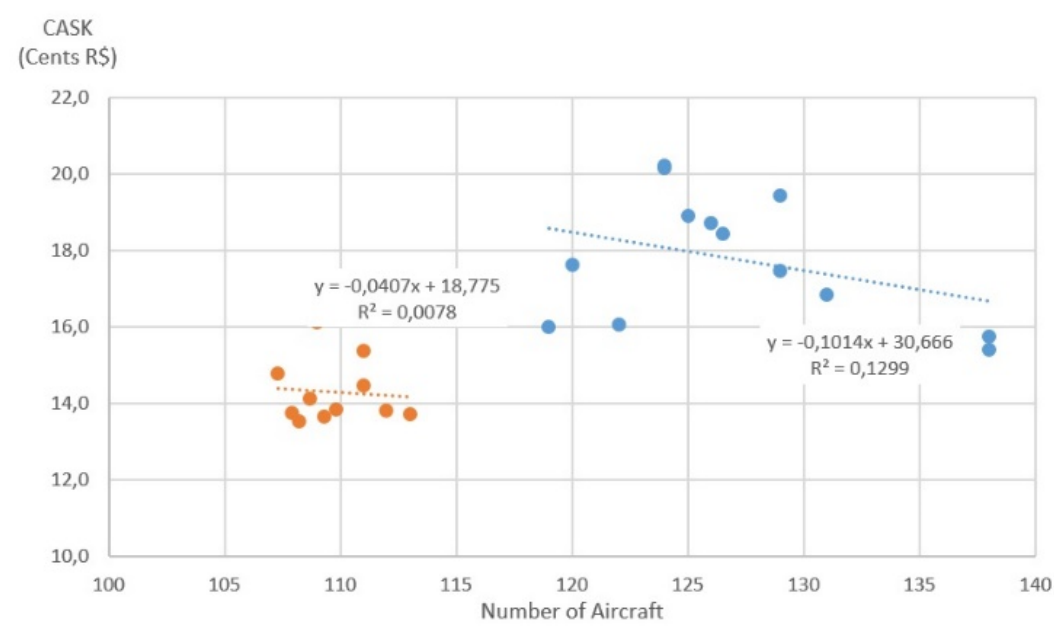

Figure 3b. CASK x Fleet size (Source: www.voegol.com.br)

Figure 4a shows the RPK increasing proportionally with fuel consumption prior to the acquisition. In fact, this trend after the acquisition decreased with a reduction of the representativeness of the linear model $\left(\mathrm{R}^{2}=0.52\right)$. Figure $\mathbf{4 b}$ shows a strong CASK scattering with fuel consumption in both samples, which may be attributed to other cost factors not related to fuel.

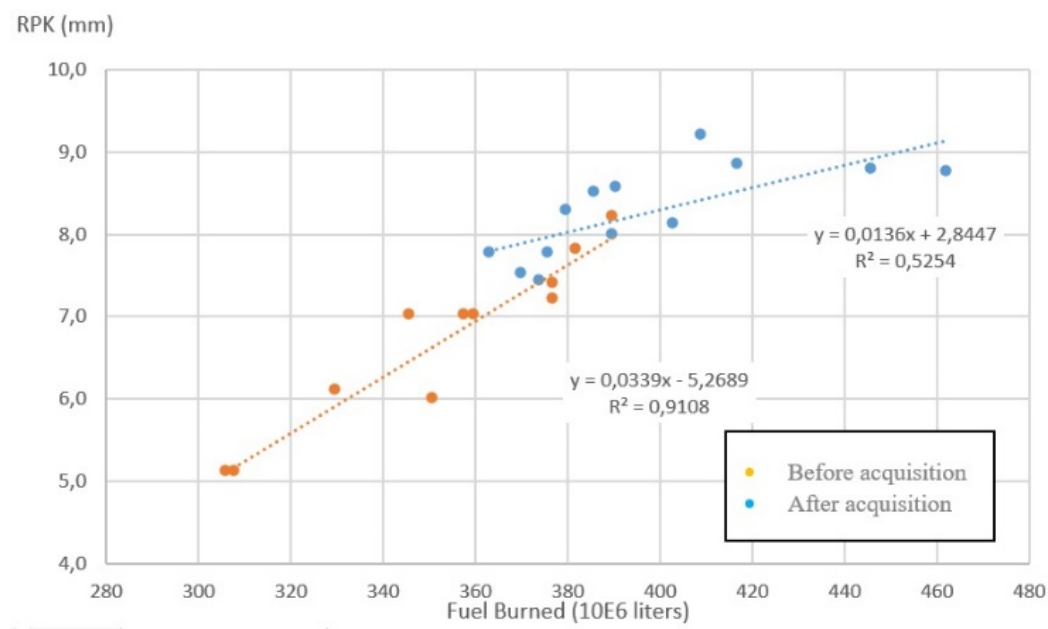

Figure 4a. RPK x Fuel Consumed (Source: www.voegol.com.br) 


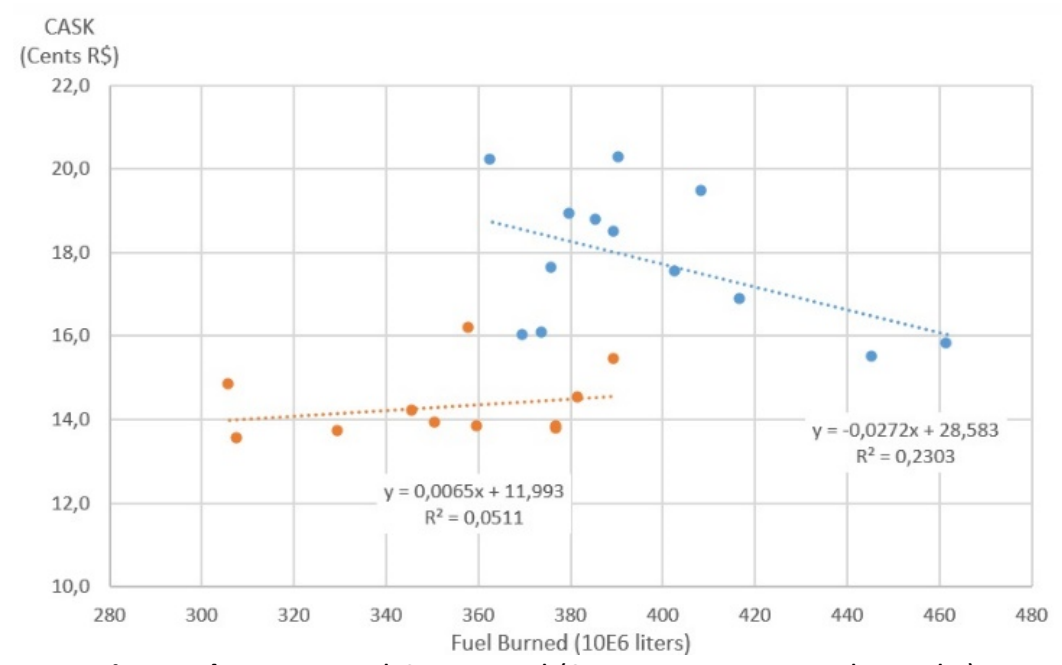

Figure 4b. RPK x Fuel Consumed (Source: www.voegol.com.br)

\section{REGRESSION RESULTS AND DISCUSSION}

In this session we present and discuss the multivariate regression results considering the selected inputs for both RPK and CASK models. Tables $2 \mathrm{a}$ and $2 \mathrm{~b}$ show the main factors of the ANOVA analysis of such regressions. Figures $5 \mathrm{a}$ and $5 \mathrm{~b}$ show the accuracy of RPK and CASK models compared with the actual values, within a $5 \%$ error band.

Table 2a: RPK regression (ANOVA analysis)

\begin{tabular}{|c|c|c|c|c|c|c|c|c|c|c|c|}
\hline \multirow{2}{*}{\multicolumn{2}{|c|}{ Coefficient }} & \multicolumn{5}{|c|}{ Before Acquisition } & \multicolumn{5}{|c|}{ After Acquisition } \\
\hline & & $\begin{array}{c}\text { Calcula- } \\
\text { ted } \\
\text { Value }\end{array}$ & $\begin{array}{l}\text { Std } \\
\text { error }\end{array}$ & $\begin{array}{c}\mathrm{t} \\
\text { stat }\end{array}$ & $\begin{array}{c}t \\
95 \%\end{array}$ & $\begin{array}{c}\mathbf{p} \\
\text { value }\end{array}$ & $\begin{array}{l}\text { Calculated } \\
\text { Value }\end{array}$ & $\begin{array}{l}\text { Std } \\
\text { error }\end{array}$ & $\begin{array}{c}\mathrm{t} \\
\text { stat }\end{array}$ & $\begin{array}{c}t \\
95 \%\end{array}$ & $\begin{array}{c}\mathbf{p} \\
\text { value }\end{array}$ \\
\hline \multicolumn{2}{|c|}{ Intercept } & 8,8114 & 9.6412 & 0.9139 & -14.7799 & 0.3960 & $-4,6213$ & 2.3350 & -1.9791 & -9.8240 & 0.0760 \\
\hline $\operatorname{Ln}(\mathrm{ASK})$ & $\mathbf{x 1}$ & 0,2257 & 0.6177 & 0.3653 & -1.2858 & 0.7274 & -1.2984 & 0.0752 & -1.8413 & -2.8695 & 0.0954 \\
\hline Ln (COMB) & $\mathbf{X 2}$ & 2.4141 & 0.9163 & 2.6346 & 0.1720 & 0.0388 & 2.5508 & 0.9981 & 2.5556 & 0.3268 & 0.0286 \\
\hline Ln (FUNC) & X3 & -1.4677 & 1.0498 & -1.3982 & -4.0364 & 0.2116 & -0.7265 & 0.2115 & -3.4348 & -1.1978 & 0.0064 \\
\hline Ln (NANV) & $\mathrm{X} 4$ & -1.5308 & 1.5108 & -1.0132 & -5.2275 & 0.3501 & 0.3561 & 0.7672 & 0.4662 & -1.3532 & 0.6525 \\
\hline \multicolumn{2}{|l|}{$R^{2}$} & \multicolumn{5}{|c|}{0.9463} & \multicolumn{5}{|c|}{0.9021} \\
\hline \multicolumn{2}{|c|}{$F(F$ significance) } & \multicolumn{5}{|c|}{$26.4168(0.0006)$} & \multicolumn{5}{|c|}{$23.0452(0.0000)$} \\
\hline \multirow{2}{*}{\multicolumn{2}{|c|}{ Homogeneity Factor ( $r$ ) }} & \multicolumn{5}{|c|}{-0.3587} & \multicolumn{5}{|c|}{0.9021} \\
\hline & & \multicolumn{5}{|c|}{ Decreasing Return of Scale } & \multicolumn{5}{|c|}{ Increasing Return of Scale } \\
\hline
\end{tabular}

Table 2b: CASK regression results (ANOVA Analysis)

\begin{tabular}{|c|c|c|c|c|c|c|c|c|c|c|c|}
\hline \multirow{2}{*}{\multicolumn{2}{|c|}{ Coefficient }} & \multicolumn{5}{|c|}{ Before Acquisition } & \multicolumn{5}{|c|}{ After Acquisition } \\
\hline & & $\begin{array}{c}\text { Calculated } \\
\text { Value }\end{array}$ & $\begin{array}{l}\text { Std } \\
\text { error }\end{array}$ & $\begin{array}{c}t \\
\text { stat }\end{array}$ & $\begin{array}{c}t \\
95 \%\end{array}$ & $\begin{array}{c}p \\
\text { value }\end{array}$ & $\begin{array}{c}\text { Calculated } \\
\text { Value }\end{array}$ & $\begin{array}{l}\text { Std } \\
\text { error }\end{array}$ & $\begin{array}{c}\mathbf{t} \\
\text { stat }\end{array}$ & $\begin{array}{c}t \\
95 \%\end{array}$ & $\begin{array}{c}p \\
\text { value }\end{array}$ \\
\hline \multicolumn{2}{|l|}{ Intercept } & 1.8320 & 0.1205 & 15.2091 & 1.5472 & 0.0000 & 1.2563 & 0.6977 & 1.8005 & -0.3220 & 0.1052 \\
\hline Ln (RPK) & $\mathbf{X 1}$ & -0.0951 & 0.0589 & \begin{tabular}{|l|}
-1.6163 \\
\end{tabular} & -0.2343 & 0.1501 & 0.1647 & 0.2353 & 0.7000 & -0.3676 & 0.5016 \\
\hline Ln (C_COMB) & $\mathbf{X 2}$ & 0.5605 & 0.1096 & 5.1155 & 0.3014 & 0.0014 & 0.5134 & 0.2126 & 2.4142 & 0.0032 & 0.0389 \\
\hline Ln (C_FUNC) & X3 & 0.0599 & 0.1379 & 0.4340 & -0.2663 & 0.6774 & 0.2675 & 0.1735 & 1.5413 & -0.1250 & 0.1576 \\
\hline Ln (C_MNT) & $\mathbf{X 4}$ & -0.0823 & 0.0219 & -3.7561 & -0.134 & 0.0071 & 0.1573 & 0.0467 & 3.3660 & 0.0515 & 0.0083 \\
\hline \multicolumn{2}{|l|}{$R^{2}$} & \multicolumn{5}{|c|}{0.8969} & \multicolumn{5}{|c|}{0.7568} \\
\hline \multicolumn{2}{|c|}{$F$ ( $F$ significance) } & \multicolumn{5}{|c|}{$15.2257(0.0015)$} & \multicolumn{5}{|c|}{$7.0004(0.0076)$} \\
\hline \multirow{2}{*}{\multicolumn{2}{|c|}{ Homogeneity Factor ( $r$ ) }} & \multicolumn{5}{|c|}{0.4429} & \multicolumn{5}{|c|}{1.1029} \\
\hline & & \multicolumn{5}{|c|}{ Scale Economy } & \multicolumn{5}{|c|}{ Scale Diseconomy } \\
\hline
\end{tabular}




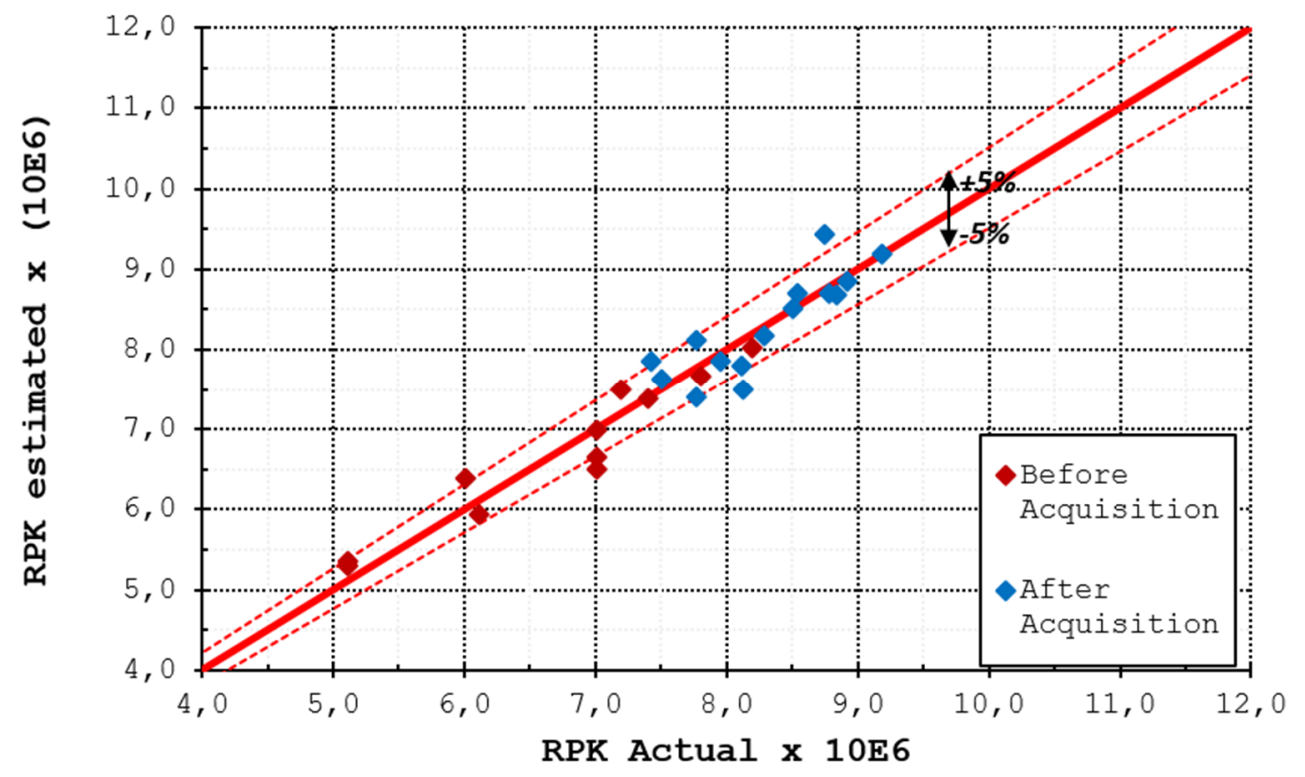

Figure 5a. RPK model accuracy

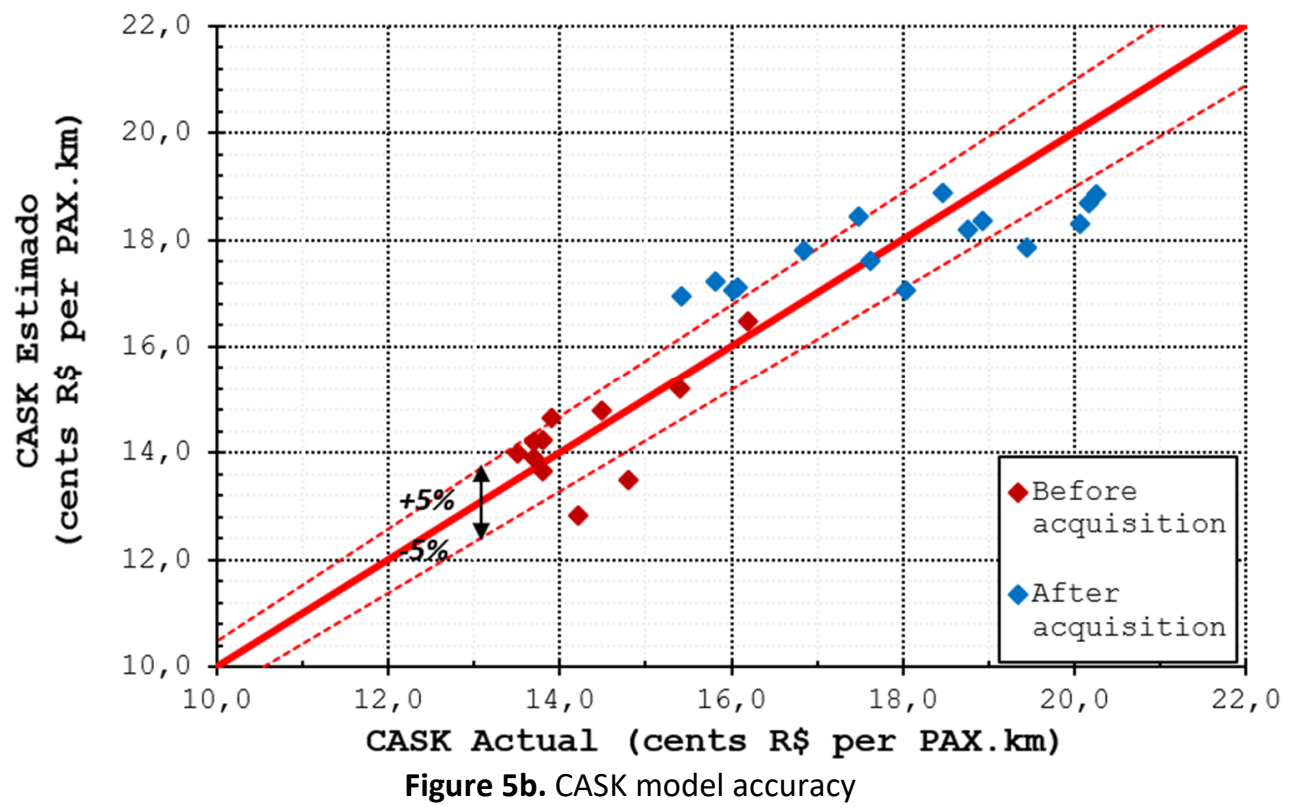

Therefore, for the pre-acquisition period (1T09-3T11) the following Cobb-Douglas functions were obtained:

$$
\begin{aligned}
& \operatorname{Ln}(R P K)=8,8114+0,2257 \cdot \operatorname{Ln}(A S K)+2,4141 \cdot \ln (C O M B)-1,4677 . . \operatorname{Ln}(F U N C)+1,5308 \cdot \operatorname{Ln} *(A N V) \\
& L n(C A S K)=1,8320-0,0951 \operatorname{Ln}(R P K)+0,5605 \operatorname{Ln}\left(C_{-} C O M B+0,0599 \cdot \operatorname{Ln}\left(C_{-} F U N C+0,0823 \operatorname{Ln}\left(C_{-} M N T\right)\right.\right.
\end{aligned}
$$

For the post-acquisition period (4T11-2T15) the following Cobb-Douglas functions were obtained:

$$
\begin{aligned}
& \operatorname{Ln}(R P K)=-4,6213-1,2984 \cdot \operatorname{Ln}(A S K)+2,5508 \ln (C O M B)-0,7265 . \operatorname{Ln}(F U N C)+0,3561 \cdot \operatorname{Ln} *(A N V) \\
& \operatorname{Ln}(C A S K)=1,2563+0,1647 \cdot \operatorname{Ln}(R P K)+0,5133 \operatorname{Ln}\left(C_{-} C O M B\right)+0,2674 \operatorname{Ln}\left(C_{-} F U N C\right)+0,1573 \operatorname{Ln}\left(C_{-} M N T\right)
\end{aligned}
$$

From the results it is possible to conclude that the log-linear models obtained for RPK presented a high degree of representativeness ( $\mathrm{R}^{2}$ greater than 0.9 in both periods). On the cost side, the CASK model also represented significantly the results, but was less representative in 
the second period ( $\mathrm{R}^{2}$ ranged from 0.8969 to 0.7568 ). The estimated outputs outside the $5 \%$ margin may be attributed to the influence of non-considered inputs.

The ANOVA analysis shows that the estimation coefficients pass the 95\% Student's t-distribution-test and F calculated much larger than significance, suggesting that the results of all regressions can be considered representative. Also, the analysis has shown that the inputs related to fuel consumption and fuel costs have significant influence on the proposed models, since their p-values are less than 0.05 between and after the acquisition. The same occurs with maintenance costs in the CASK model.

The production return of scale calculated via RPK model after the acquisition, approached the unit value which means that diminishing returns of scale are present. This is an expected effect observed in airlines with large fleets, specifically over twenty aircraft (Doganis, 2001). This suggests that the economy of scale achieved did not provide an efficient growth for the company despite increasing the number of routes, aircraft and staff. On the cost side, diseconomies of scale after the acquisition have been observed, suggesting an increase in costs probably motivated by the replication of administrative features of the two companies for a certain period.

The positive elasticity of production with respect to fuel consumption in both periods presented almost the same magnitude, which is consistent with the expected result (higher consumption, more flights, bigger production). The small variation of this value suggests that the operational standards of both companies may be similar and therefore no major changes occur on how pilots operate the aircraft. In fact, this is supported by the incorporation of the Webjet Boeing 737-300 fleet into GOL Boeing 737-700 / 800, variants of the same model. Indeed, this fleet growth has shown positive impact on the elasticity of production in relation to the number of aircraft.

The elasticity of production in relation to the number of employees, which was negative in both periods, shows that probably there were not enough efforts in place to improve the production efficiency after the acquisition, despite some slight improvement of this value. In the second period, the elasticity of costs in relation to the number of employees became significantly more positive, suggesting that the measures taken for headcount reduction in the following months had unsuccessful effects on operating costs. In addition, the route superposition may have impacted on the number of employees in the short term, once a duplicated number of employees and enhanced infrastructure were present at the related stations.

However, it can be noticed that the elasticity of maintenance costs was the parameter that mostly increased, possibly because of the difficulty of adapting to significantly different maintenance management methodologies adopted in both fleets before the acquisition.

The Webjet routes incorporation into GOL's network possibly diluted the traffic where both companies were most likely competitors, reducing the utilization efficiency. The authors believe that this is the cause of the signal reversal of production elasticity related to the ASK. Also, a significant positive jump of the elasticity of costs in relation to this input can be observed, suggesting that the new seats offered from the incorporation of the new fleet and incremental staff

\section{CONCLUSIONS}

In the present research, we studied the impact on air transport production and costs after the acquisition of the LCC Webjet by VRG Linhas Aéreas (so called GOL Airlines) in October 2011. 
Cobb-Douglas functions were designed to model RASK and CASK in the periods 12 months before and after the acquisition.

A multivariate log-linear regression was used to determine the associate elasticities of the production and cost functions regarding the selected input variables. On the production side (RASK) the following inputs were selected: ASK (available seat kilometer), fuel consumption, number of employees and fleet size. On the cost side (CASK) the following inputs were considered: RASK, fuel costs, maintenance costs and labor costs.

The selected model has shown a very good correlation between the selected inputs and outputs in both periods ( $\mathrm{R}^{2}$ greater than 0.9 for RASK and greater than 0.75 for CASK) and can therefore be considered adequate for the proposed analysis. With the present analysis, the identification of important inefficiencies was possible, mainly related to increased number of seats offered in previous competing routes (duplicated after the acquisition) and increased number of employees after the acquisition. In addition, decreasing productivity and increased initial operating costs (especially in relation to maintenance and personnel) turned out to be the biggest challenge for the group, and were not completely sorted out until the last period of the analysis. Finally, diseconomies of scale were identified after the acquisition, suggesting increasing costs due to the duplication administrative features of the two companies.

Therefore, it has been demonstrated that the Cobb-Douglas function may be used as an effective and simple modeling tool in the evaluation of the impact on production (RPK) and costs (CASK) after the acquisition of an airline by another one. The authors propose that this methodology be applied in short term analysis and consider it therefore adequate to be used for tactical decisions of airlines.

Although the selected inputs for both models were adequate for this proposal, it is worth mentioning that there may be other non-operational factors (i.e. cost of capital and infrastructure) that may impact the results, which were not included in this selected set of inputs These factors can be addressed in future research developments.

\section{REFERENCES}

ABEAR (2014). Panorama 2014:O setor aéreo em dados e análises. Associação Brasileira das Empresas Aéreas. São Paulo, Brasil.

Barros Junior, J. R. S. N. (2007). Custos no Transporte Aéreo: Determinantes e Modelos. Journal of Transport Literature (RELIT) Vol.1, n.2, pp.70-109 Jul 2007. São José dos Campos, Brasil.

Bao Hong, T. (2008). Cobb-Douglas Production Function. European Economy Seminar. NOVA School of Business. Lisbon, Portugal.

Bettini, H. F. A. J. e Oliveira, A. V. M. (2011) Transporte aéreo regional: entre economias de densidade e custos de transação. Journal of Transport Literature, vol. 5, n. 4, pp. 171-187.

Caves, D.W.; Christensen, L. R. e Threteway, M.W. (1984) Economics of Density Versus Economies of Scale: Why Trunk and Local Service Airline Costs Differ. Rand Journal of Economics, v. 15, p. 471-489. DOI: 10.2307/2555519

Cobb, C.W. e Douglas, P.H. (1928). A Theory of Production. American Economic Association, pp.139-165. New York, United States of America.

Doganis, R. (2001). The Airline Business in the 21st Century. London: Routledge, 1st. Edition, 2001.

Fregnani, J. A.T. G.; Ferreira, N. S. e Gabrieler M. C. (2009). Análise dos Custos Logísticos no Transporte Aéreo Regional. Journal of Transport Literature (RELIT) Vol.3, n.2, pp.7-25 Jul 2009. São José dos Campos, Brasil.

Kuroda, E. T.; Kalfas, A. J. e Eller, R. A. G. (2012). Aplicação da função Cobb-Douglas para a análise da produtividade no setor aéreo. Journal of Transport Literature (RELIT) Vol.6, n.2, pp.169-179 abril 2012. São José dos Campos, Brasil. DOI:10.1590/S2238-10312012000200009

Martins, F. G. D.; Da Silva, F.; G. F., Rocha, C. H.; Queiroz, M. e Araújo, C. E. F. (2012) Análise de eficiência estimando fronteiras paramétricas Cobb-Douglas e translog: o caso de empresas de transporte rodoviário interestadual de passageiros por ônibus no Brasil. Journal of Transport Literature, vol. 6, n. 3. DOI: 10.1590/S2238-10312012000300002

Silveira, J. A. (2003). Transporte Aéreo Regular no Brasil: Análise econômica e função de custo. Dissertação de Mestrado. Universidade Federal do Rio de Janeiro. COPPE, 2003. 
GOL (2012). Comunicados e Fatos Relevantes 10/12/2012: GOL Anuncia Aprovação pelo CADE para Aquisição da Webjet. VRG Linhas Aéreas. SãoPaulo, Brazil.

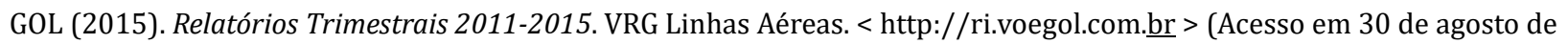
2015)

Yang, X. e Zhu, Y. (2015). The Analysis of Technical Efficiency of Airlines in China. International Conference on Mechatronics, Electronic, Industrial and Control Engineering (MEIC 2015). Atlantis Press. 